\title{
In Search of Key HR Practices for Improvement of Productivity of Employees in the KIBS Sector
}

\author{
Agnieszka Wojtczuk-Turek'
}

ABSTRACT

\begin{abstract}
The objective of this article is to present research devoted to the relationships between HR practices and productivity (understood as behavior and results) of employees in the KIBS sector (knowledgeintensive business services sector). The operations of companies in this sector are based on the application of expert knowledge to create services satisfying the needs of personalized clients. Because companies from the KIBS sector are immensely important to the development of the economy (mainly in the context of their high potential for innovation), identification of the key factors that allow them to give fine performance is a significant theoretical and practical issue. A major role in this respect is played by the human resources management system - chiefly because KIBS companies gain competitive advantage though employees' knowledge. As part of research with a quantitative approach (serving to test hypotheses) and a qualitative approach (allowing exploration), the human resources management system has been described as the key - from the point of view of desired behaviors and results - HR practice identified. Based on the study that has been conducted, which examined employees who had expert knowledge and created personalized services for clients, it has been concluded that the HR practices that most fully account for the productivity of employees are work design and job characteristics and empowerment, participation, and autonomy. Within the framework of qualitative research carried out in participation with HR managers of knowledge-intensive service firms, the character of individual high performance HR practices and the prominent role of managers and HR experts in supporting performance on individual and organizational levels has been indicated.
\end{abstract}

KEY WORDS: $\quad$ KIBS sector, knowledge-based work, HR practices, behaviors, results.

JEL Classification: M12, L2

${ }^{1}$ Warsaw School of Economics, Poland

\section{Introduction}

The increasing economic pressure on knowledge and innovation has stirred the emergence and development of companies offering business services based on

\section{-}

Correspondence concerning this article should be addressed to: Agnieszka Wojtczuk-Turek Institute of Human Capital, Warsaw School of Economics. Aleja Niepodległości 162, 02-554 Warsaw, Poland, E-mail: awojtc@sgh.waw.pl expert knowledge (i.e., KIBS - knowledge-intensive business services sector). The criterion for distinguishing such companies from others on the market is the fact that their services are based on expert knowledge that is employed for the purpose of satisfying the needs of personalized clients (Bettencourt, Ostrom, Brown, \& Roundtree, 2002). These include both services that make extensive use of scientific and technological knowledge, e.g., research and development or IT ser- 
vices, and more traditional, professional, e.g., legal or accounting, services (Miles, 2005).

The significance of these companies for the development of the economy is not only profound from the perspective of innovative potential but also because they may trigger and enhance knowledge conversion processes in clients' companies (den Hertog, 2000). In this context, identification of the key factors contributing to high efficiency and effectiveness in companies operating in the KIBS sector is an important theoretical and practical issue. Because the operations of these companies are based on application of expert knowledge while the creation of services is dependent on the ability of a company to make use of its resources that employees possess (Larsen, 2001), particular significance in the process of building competitive advantage is assumed by human resources management (HRM).

Taking into consideration companies' objectives related to achieving high individual and organizational productivity, it is recommended to adopt High Performance Work Systems (HPWS) along with High Performance Work Practices (HPWP) in human resources management, highlighting involvement, joint participation, and effects (Becker \& Huselid, 1998; Huselid, 1995; Messersmith \& Guthrie, 2010; Posthuma, Campion, Masimowa, \& Campion, 2013; Tregaskis, Daniels, Glover, Butler, \& Meyer, 2013). In addition, although numerous studies pointing to a positive correlation between these systems and high task results of employees exist, there are still many unresolved issues, including, among others, the influence that HRM mechanisms exert on efficiency and effectiveness is insufficiently explained (Becker \& Gerhart, 1996; Purcell, Kinnie, Hutchinson, Rayton, \& Swart, 2003), no intervening variables are taken into account in analyses (Huselid \& Becker, 1996), and the characteristic nature of service firms is disregarded - the majority of examinations are chiefly based on production companies, whereas some of their practices are inadequate for service firms $(\mathrm{Fu}$, Flood, Bosak, Morris, \& O’Regan, 2015). Hence the problems that have been indicated give rise to new research areas.

The aim of this article is to present research on the relationship between HR practices and productivity of employees who create services based on intensive expert knowledge as well as to characterize the human resources management system in companies operating in the KIBS sector.

\section{The role of high performance HR practices in stimulation of knowledge workers' productivity}

Empirical studies demonstrate that there are correlations between HPWS and both individual and organizational results. The system is positively related to organizational performance (Bowen \& Ostroff, 2004; Guthrie, 2001; Huselid, 1995) as well as human capital on the individual level (Chang, 2015). As far as the second aspect is concerned, the results generated by employees are crucial for demonstrating organizational effectiveness (Zhang \& Morris, 2014). In the course of specifying the mechanism of influence of HPWS on individual results, the impact of human resources management on employees' skills, knowledge, motivation, and elasticity is presented (Paauwe \& Richardson 1997).

Analyses that researchers conduct prove that the effects arising from high performance work systems on individual levels are related to both 1) behavioral effects: proactivity (Evans \& Davis, 2015), organizational engagement (Garg, 2015, Macky, \& Boxall, 2007), creativity (Zhu \& Chen, 2014), employees' effectiveness (Demirbag, Collings, Tatoglu, Mellahi, \& Wood, 2014), and 2) attitudes: job satisfaction (García-Chas, Neira-Fontela \& Castro-Casal, 2014; Garg, 2015; Gibas \& Ashill, 2013; Yanadori \& Jaarsveld, 2014), satisfaction from HPWS (Zhang, Fan \& Zhu, 2014), and the sense of procedural justice (García-Chas et al., 2014). The attitude-related aspects are immensely important from the point of view of the emergence of intentions to display desired organizational behaviors, which in turn lead to results. Therefore, from the perspective of operationalization of productivity at the individual level, one should discuss not only results but also behaviors since along with attitudes they are important elements constituting workers' productivity. Authors stress that the very theories of organizational behaviors serve as a basis for accounting for individual efficiency (Aguinis, O’Boyle, Gonzalez-Mulé, \& Joo, 2015). They refer to measures of individual behaviors and their aggregation as well as indicators of results (Beck, Beatty, \& Sackett, 2014). An example of integration of both these perspectives is a definition of productivity that is 



\section{Method}

The aim of the quantitative study is to examine the relationships between individual HR practices and productivity of employees that create services for clients. As part of determination of the character of these relationships, an attempt has also been made to demonstrate which HR practices accounting for productivity are understood as behaviors and create results to the largest extent. The main hypothesis is concerned with the existence of a statistically significant correlation between high performance HR practices and employees of companies in the KIBS sector. To verify this hypothesis, independent regression analyses for individual practices have been carried out. The objective of the qualitative study is examination of the character of human resources management in knowledge-intensive service firms and capturing the nature of individual HR practices.

The research sample was composed of employees of companies operating in the KIBS sector $(\mathrm{N}=563)$, whose work consisted of performing tasks requiring expert knowledge and creating services for clients. The workers were employed in large- and medium-sized companies and various knowledge-intensive service branches: telecommunications; software, IT consulting, and related activity; information service activities; activities of head offices; management consultancy activities; architecture and engineering activity; research and technical analyses; scientific research and development; advertising; market research and opinion polls; and other professional, scientific, and technical activities. The study was Poland-wide and conducted in 2015 with the use of Computer Assisted Telephone Interviews (CATI), which ensured anonymity.

HR managers who co-create and follow HR policies of companies operating in the KIBS sector took part in the qualitative study. Ten individual partly structured in-depth interviews (IDI) were conducted.

For the purpose of measurement of HR practices, statements derived from tools used for examination of HR practices were adopted (Fu et al. 2015; Guthrie, 2001; Huselid, 1995; Tsai, 2006), which referred to conceptualization of high performance work systems. Based on exploratory analysis of the factors, the following practices were discerned: motivating, training, and professional development (promotion); work design and job characteristics; knowledge management; empowerment, participation, and autonomy; performance evaluation and management; team work.

Diagnosis of employee productivity is established on the basis of measurement of aggregated innovative, prosocial, and proactive behaviors and results. Their detailed characterization along with reliability parameters and analysis of the factors are provided in a paper by Wojtczuk-Turek (2016), which employs indicators recommended by the relevant literature: accomplishment of objectives, timely performance of tasks (Janz, Colquitt \& Noe, 1997), client satisfaction, quality, project significance and success (Drucker, 1999; Janz, Colquitt, Noe \& 1997), and innovative effects (Drucker, 1999).

\section{Results}

In the first stage of analysis, the values of the coefficients of correlation for individual variables were estimated (Table 1).

As far as individual practices (Table 1) are concerned, it may be stated that productivity (in general) is most strongly correlated with work design and job characteristics $(\mathrm{r}=0.452 ; \mathrm{p}<0.01)$, empowerment, participation, and autonomy $(\mathrm{r}=0.359 ; \mathrm{p}<0.01)$ and, to a smaller extent (but still statistically significant), with performance management and appraisal $(\mathrm{r}=0.278 ; \mathrm{p}<0.01)$ and knowledge management $(\mathrm{r}=0.270 ; \mathrm{p}<0.01)$

The results revealed that a significant correlation was found with all HR practices, and the strongest was revealed in the case of work design and job characteristics $(r=0.308 ; \mathrm{p}<0.01)$ and performance management and appraisal $(r=0.249 ; \mathrm{p}<0.01)$. The mutual correlations between HR practices and productivity / results, which were discovered in the study, served as basis for further exploratory analyses. To determine the type of correlation between productivity and HR practices and indicate which of them account for employee productivity to the largest extent; independent regression analyses were conducted (separately for each variable as factors in the same theoretical construct which are strongly statistically correlated with one another may not be examined with a single regression model) on a sample of employees under analysis, $\mathrm{N}=563$. Juxtaposition of the results of analysis are presented in Table 2.

Based on the regression analysis that has been carried out, it may be stated that the practices that ac- 
Table 1. Descriptive statistics and values of coefficients of correlation for HR practices and productivity

\begin{tabular}{|c|c|c|c|c|c|c|c|c|c|c|c|}
\hline Variables & $M$ & SD & 1 & 2 & 3 & 4 & 5 & 6 & 7 & 8 & 9 \\
\hline 1. HRM PR GEN. & 3.50 & 0.45 & 1 & & & & & & & & \\
\hline 2. MT\&R & 3.13 & 0.72 & $.816^{* *}$ & 1 & & & & & & & \\
\hline 3. WDJC & 4.01 & 0.58 & $.500^{* *}$ & $.118^{* *}$ & 1 & & & & & & \\
\hline 4. KM & 3.52 & 0.63 & $.677^{* *}$ & $.433^{* *}$ & $.268^{* *}$ & 1 & & & & & \\
\hline 5. EPA & 3.39 & 0.75 & $.585^{* *}$ & $.335^{* *}$ & $.377^{* *}$ & $.211^{* *}$ & 1 & & & & \\
\hline 6. PM\&A & 3.68 & 0.76 & $.725^{* *}$ & $.613^{* *}$ & $.191^{* *}$ & $.398^{* *}$ & $.369^{* *}$ & 1 & & & \\
\hline 7. TM & 3.84 & 1.00 & $.333^{* *}$ & $.127^{* *}$ & $.265^{* *}$ & $.109^{* *}$ & $.123^{* *}$ & $.126^{* *}$ & 1 & & \\
\hline 8. RS & 3.93 & 0.49 & $.339 * *$ & $.196^{* *}$ & $.308^{* *}$ & $.218^{* *}$ & $.202^{* *}$ & $.249^{* *}$ & $.101^{*}$ & 1 & \\
\hline 9. PR-GEN. & 3.78 & 0.50 & $.452^{* *}$ & $.246^{* *}$ & $.452^{* *}$ & $.270 * *$ & $.359^{* *}$ & $.278^{* *}$ & $.159^{* *}$ & $.499^{* *}$ & 1 \\
\hline
\end{tabular}

Note. ${ }^{*} \mathrm{p}<0.05,{ }^{* *} \mathrm{p}<0.01$

HRM PR GEN. - HRM practices in general, MT\&R - motivating, training, and development, WDJC - work design and job characteristics, $\mathbf{K M}$ - knowledge management, EPA - empowerment, participation, autonomy, PM \&A- performance management and appraisal, TM - team work, RS - results, PR-GEN. - productivity in general.

Table 2. Juxtaposition of regression analysis results for individual predictors of productivity

\begin{tabular}{lcccccccc}
\hline Predictors & B & $\begin{array}{c}\text { Standard } \\
\text { error }\end{array}$ & Beta & t & $\begin{array}{r}\text { Significance } \\
\text { of t }\end{array}$ & F & $\begin{array}{c}\text { Significance } \\
\text { of F }\end{array}$ \\
\hline Work design and job characteristics & .355 & .029 & .461 & 12.296 & .000 & 151.186 & .000 \\
Empowerment, participation, and autonomy & .208 & .023 & .352 & 8.916 & .000 & 79.499 & .000 \\
Performance management and appraisal & .176 & .023 & .302 & 7.514 & .000 & 56.466 & .000 \\
Knowledge management & .203 & .029 & .287 & 7.084 & .000 & 50.188 & .000 \\
Motivating, training, and development & .160 & .025 & .260 & 6.378 & .000 & 40.677 & .000 \\
Team work & .071 & .019 & .160 & 3.832 & .000 & 14.688 & .000 \\
\hline
\end{tabular}

count for employee productivity - understood as aggregated behaviors and results - to the largest extent are work design and job characteristics and empowerment, participation, and autonomy. The first group of practices is immensely important in the context of work based on intensive knowledge, and the second group is significant with respect to encouragement of employees' engagement.

The qualitative study, which played an exploratory role, supplemented and deepened the quantitative one. Within the framework of in-depth interviews with HR managers, the researcher tried to capture the character of human resources management in companies creating specialist services for clients.
While discussing the role of the human resources management system in (large- and medium-sized) companies operating in the KIBS sector (which usually have structurally separate HR departments that implement an HR policy), one should refer to the specific character of these firms as their competitive advantage is based on competences; among others, innovation, building effective relations, orientation at the client and results, and engagement. The resource of particular importance is knowledge that underlies creation of highly specialized services. Clients play a major role in the process of creation of such services as they supply the necessary knowledge and offer very close cooperation in co-creating solutions. Strong co- 
operation between the client and supplier is predominantly connected with high personalization of services and expectations of uniqueness.

Basing competitive advantage on knowledge and experience of employees endows the HR department and HRM operations with very specific roles. Managers (especially the ones in large companies) who took part in the interviews consistently stressed the strong position of the HR department and HR managers. This role may be referred to as HR business partnering, which manifests itself as the active participation of $\mathrm{HR}$ managers and experts in decision-making and operations concerning certain organizational units.

In light of HR managers' opinions, the main objectives of the HRM policy in companies creating highly specialized services are strategic partnership and playing the role of the agent of change. The respondents also pointed to support and safety but to a smaller extent. Support is concerned with managers who are internal clients of the HR department. They are provided with tools and solutions that allow them to single-handedly perform HR activities. These tools and solutions disperse and cascade HR activities to line managers who stay close to employees and have the most thorough knowledge of the character of their work. It is particularly important in the context of immense work complexity, which requires support and fine performance of design teams. Therefore, the attributes of human resources management systems in companies from the KIBS sector are openness (i.e., high accessibility for employees) and full cooperation with the managers.

In addition, in light of the respondents' answers, it turns out that despite the existence of structurally separate HR departments, HRM activities are even more dispersed, as they are performed (not only by the managerial staff but also) by employees themselves, who take part in the process of delegation and distribution of tasks as well as recruitment for highly specialized positions in the company (as persons verifying the knowledge and technical skills of the candidates).

Another attribute of the HRM system in knowledge-intensive firms indicated by the respondents is flexibility manifesting itself as, among other things, application of various forms of organization of working time - flexible working time or making use of various types of contracts. Job descriptions are not always in place since tasks may arise out of needs, requirements, and conditions specific to a given project, and it may so occur that employees will be performing completely new tasks. Freedom of action in some companies consists of employees establishing their own tasks and working time, though they may not give up certain tasks; companies' use of the services of off-site workers and working time may be regulated. Of course, this is not a rule, as there were also responses indicating that quite stiff - scheduled and structured - organization of work was in place.

An important element of enhancing employee productivity in companies from the KIBS sector is management of workers' mobility. It may be the consequence of both an international character of projects (requiring cooperation with experts) and the fact that it is a good way to acquire unique knowledge that experts from various environments possess. Transfer of employees to other departments, delegating them to new tasks or borrowing employees across departments are quite common practices.

From the perspective of operation of companies from the KIBS sector, participation in creation and transfer of knowledge across the company are significant activities of the HR department. The respondents highlighted that human resources management activities are oriented at encouraging knowledge sharing at least by way of making employees assume the roles connected with entering into useful discussions (i.e., "knowledge networks" management). Another area of an HR department's activity is involvement in managing knowledge, e.g., through coordination of knowledge exchange between certain organizational units or administrating its acquisition, transfer, and protection. Wide application of IT systems, including technological HR support systems - the so-called e-HR - serves this purpose.

The interviews that were conducted also allowed to identify individual HR practices and define their character. Synthetic juxtaposition of these is presented in Table 3.

\section{Discussion on the results and conclusions}

The study was concerned with empirical verification of the assumption that there is a relationships between high performance HR practices and productivity of 
Table 3. Juxtaposition of HR practices in companies of the KIBS sector and their character

\begin{tabular}{|c|c|}
\hline HPWP practices & Analytical remarks on the character of HRM practices and outliers \\
\hline $\begin{array}{l}\text { Work design } \\
\text { and job characteristics }\end{array}$ & $\begin{array}{l}\text { - job descriptions specifying tasks are in place or not and in case of the latter, tasks are assigned } \\
\text { - } \quad \text { according to the nature of a project } \\
\text { - } \quad \text { fpecific competences (selection of competences according to tasks) } \\
\text { - } \quad \text { various forms of organization of work (e.g., off-site work), the possibility to regulate time required } \\
\text { - } \quad \text { emperform tasks, task-oriented system of work } \\
\text { - } \quad \text { flexibility of work design and the manners of performing work } \\
\text { - } \quad \text { in case of a complex project involving a large number of people, work is more organized and } \\
\text { scheduled according to deadlines }\end{array}$ \\
\hline Motivating & $\begin{array}{ll}\text { - } & \text { individualization of the motivating system } \\
\text { - } & \text { various forms of financial and non-financial motivation } \\
\text { - } & \text { motivating character of projects, which allows employees to acquire unique competences and } \\
\text { - } & \text { high attractiveness of employment } \\
\text { - } & \text { company's profit sharing } \\
& \text { rewards for innovation }\end{array}$ \\
\hline $\begin{array}{l}\text { Trainings and } \\
\text { development }\end{array}$ & 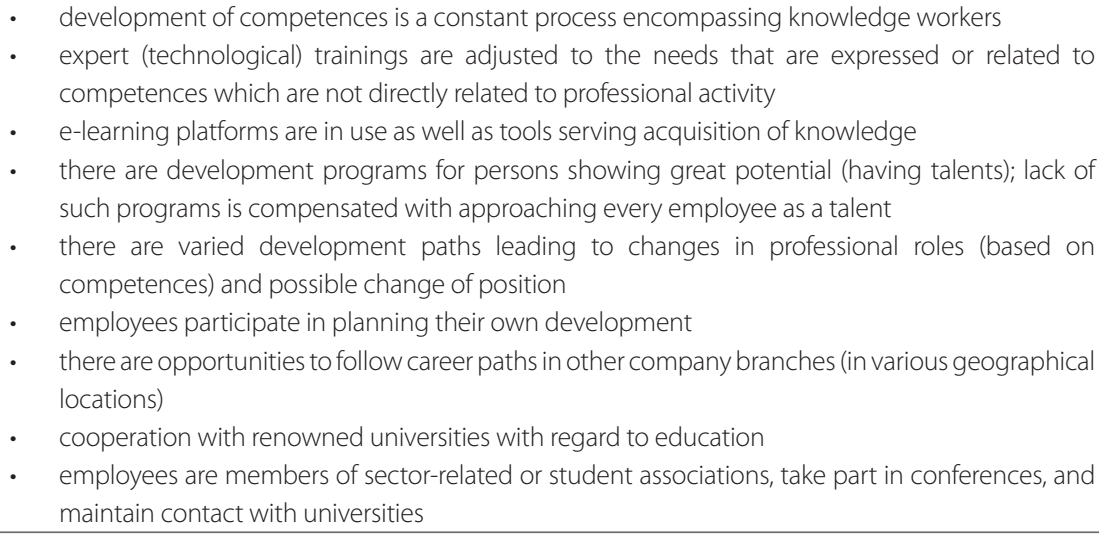 \\
\hline $\begin{array}{l}\text { Recruiting and } \\
\text { selection }\end{array}$ & 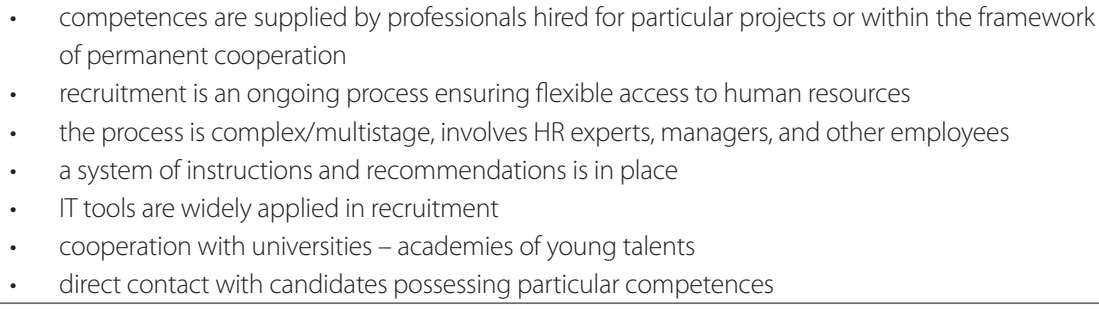 \\
\hline Appraisal & $\begin{array}{l}\text { - evaluation is carried out by managers in cooperation with the HR every half a year or every year } \\
\text { - } \text { and consistent with the financial plan ( } 360 \text { degree feedback is used) } \\
\text { - } \quad \text { compoing assessment and feedback provided during project monitoring } \\
\text { - in addition to a point-based system, there is also a descriptive system in use (based on qualitative } \\
\text { criteria) } \\
\text { - international cooperation is subject to evaluation } \\
\text { - employees participate in defining objectives and directions for development based on evaluation }\end{array}$ \\
\hline
\end{tabular}


Table 3. Continued

\begin{tabular}{|c|c|}
\hline HPWP practices & Analytical remarks on the character of HRM practices and outliers \\
\hline $\begin{array}{l}\text { Knowledge } \\
\text { management }\end{array}$ & 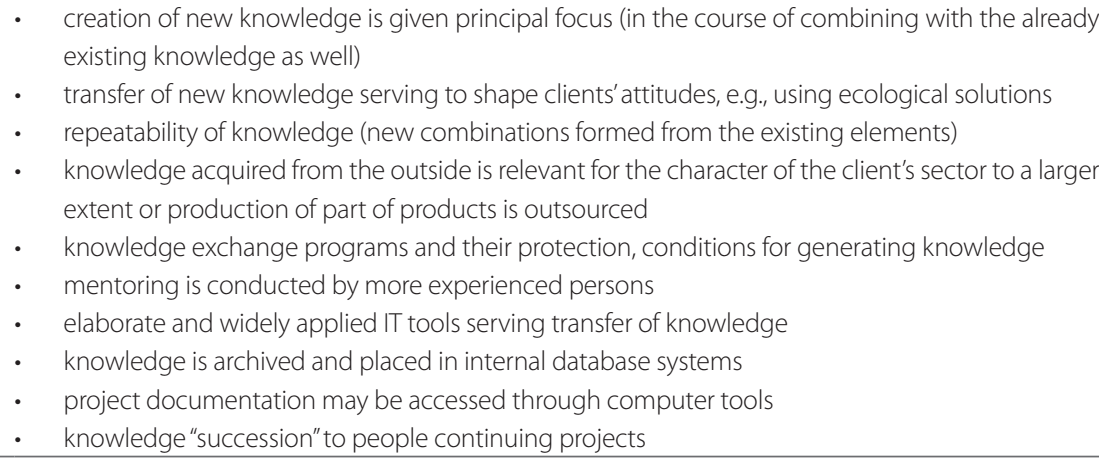 \\
\hline $\begin{array}{l}\text { Performance } \\
\text { management }\end{array}$ & $\begin{array}{l}\text { - } \quad \text { the term "effectiveness management" is in use } \\
\text { - } \quad \text { effectiveness/quality management is activity undertaken within the framework of HRM }\end{array}$ \\
\hline $\begin{array}{l}\text { Participation and } \\
\text { autonomy }\end{array}$ & $\begin{array}{l}\text { - } \quad \text { employees participate in making decisions regarding their work (e.g., tasks are distributed, it is } \\
\text { possible to give a task up) } \\
\text { - } \quad \text { workers participate in making decisions concerned with their professional development } \\
\text { - } \quad \text { workers are encouraged to take part in discussions about new implementations } \\
\text { - } \quad \text { tasks are clearly defined at some positions and may not be changed }\end{array}$ \\
\hline $\begin{array}{l}\text { Mobility } \\
\text { management }\end{array}$ & $\begin{array}{l}\text { - } \text { HR activity connected with management of international mobility is extensive (there might even } \\
\text { be a separate department) } \\
\text { - } \quad \text { serves project implementation by international teams } \\
\text { - } \quad \text { allows for acquiring of unique knowledge }\end{array}$ \\
\hline
\end{tabular}

Source: Wojtczuk-Turek, A. (2016).

employees whose work is based on intensive knowledge. While designing the study, the researcher strived to respect the assumption that positive effects arising from the influences of human resources management are the outcome of the adoption of a set of practices rather than single practices (Combs, Liu, Hall, \& Ketchan, 2006).

Analyses allowed to single out the practices that to the largest extent account for workers' behaviors and the results they achieve (even though all the HR practices under examination were significantly correlated with employee productivity). These are work design and job characteristics as well as empowerment, participation, and autonomy. It may thus be said that in the context of specific knowledge-based work in companies from the KIBS sector, activity related to creation of various tasks and enrichment of work, the requirement of intense creativity and the necessity to make use of various skills while simultaneously ensuring freedom of operation and that employees are treated individually contribute both to display of desired (innovative, proactive, and prosocial) organizational behaviors as well as achieving results. From the point of view of work design, it is important to offer such a structure of task performance which will encourage engagement and simultaneously create possibilities for effective operation. The content of work itself can offer motivation, which is indicated by J. Hackman and G.R. Oldham (1976), similarly to autonomy that is strongly correlated with the sense of satisfaction (Coutts \& Gruman, 2012). Simultaneously, the studies conducted so far confirm that participation and empowerment are 

ing about individual results. This is because it turns out that employees' perception of the effectiveness of practices is important for the implementation of HPWS. From the perspective of conceptualization of the research area, it should perhaps be expanded to cover the aspects reflecting the perspective of the HIWP (High Involvement Work Practices), as this might contribute to identification of other manners in which HRM enhances individual and organizational efficiency.

\section{References:}

Aguinis, H., O’Boyle, E., Gonzalez-Mulé, E., \& Joo, H. (2015). Cumulative advantage: Conductors and insulators of heavy-tailed productivity distributions and productivity stars. Personnel Psychology, 69(1), 3-65.

Beck, J. W., Beatty, A. S., Sackett, P. R. (2014). On the distribution of job performance: The role of measurement characteristic in observed departures from normality. Personnel Psychology, 67(3), 531-566.

Becker, B. E., Huselid, M. A. (1998). High performance work systems and firm performance: A synthesis of research and managerial applications. In G. R. Ferris (Ed.), Research in personnel and human resource management (Vol. 16, pp. 53-101). Greenwich, CT: JAI Press.

Becker, B. E., Gerhart, B. (1996). The impact of human resource management on organizational performance: Progress and Prospects. The Academy of Management Journal, 39(4), 779-801.

Bettencourt, L. A., Ostrom, A. L., Brown, S. W., \& Roundtree, R. I. (2002). Client co-production in knowledge-intensive business services. California Management Review, 44(1-2), 29-46.

Bowen, D., Ostroff, C. (2004). Understanding HRMfirm performance linkages: The role of the 'strength' of the HRM system. Academy of Management Review, 29(2), 203-221.

Brewster, C., Larsen, H. H. (Eds.), (2000). Human Resource Management in Northern Europe: Trends, Dilemmas and Strategy. Oxford, UK: Blackwell Publishers Ltd.

Camelo-Ordaz, C., García-Cruz, I., Sousa-Ginel, E., Valle-Cabrera, R. (2011). The influence of human resource management on knowledge sharing and innovation in Spain: The mediating role of affective commitment. The International Journal of $\mathrm{Hu}$ man Resource Management, 22(7), 1442-1463.
Chang, Y. Y. (2015). A multilevel examination of highperformance work systems and unit-level organisational ambidexterity. Human Resource Management Journal, 25(1), 79-101.

Chow, I. H. S., Gong, Y. (2010). The linkage of HRM and knowledge-related performance in china's technology-intensive industries. The International Journal of Human Resource Management, 21(8), 1289-1306.

Collins, C. J., Smith, K. G. (2006). Knowledge exchange and combination: The role of human resource practices in the performance of high-technology firms. Academy of Management Journal, 49(3), 544-560.

Combs, J., Liu, Y., Hall, A., \& Ketchan, D. (2006). How much do high-performance work practices matter? A meta-analysis of their effects on organizational performance. Personnel Psychology, 59(3), 501-528.

Coutts, L.M., Gruman, J.A. (2012). Applying social psychology to organizations. In F.R. Schneider, J. A. Gruman, L. M. Coutts (Eds.), Applied social psychology (pp. 217-244). Thousand Oaks, CA: Sage.

Demirbag, M., Collings, D., Tatoglu, E., Mellahi, K., \& Wood, G. (2014). High-performance work systems and organizational performance in emerging economies: Evidence from MNEs in Turkey. Management International Review, 54(3), 325-359.

Den Hertog, P. (2000). Knowledge intensive business services as co-producers of innovation. International Journal of Innovation Management, 4(4), 491-528.

Drucker, P. F. (1999). Knowledge-worker productivity: The biggest challenge. California Management Review, 41(2), 79-85.

Evans, W. R., Davis, W. D. (2015). High-performance work systems as a initiator of employee proactivity and flexible work processes. Organizational Management Journal, 12(2), 64-74.

Fu, N., Flood, P.C., Bosak, J., Morris, T., O’Regan, P. (2015). How do high performance work systems influence organizational innovation in professional service firms? Employee Relations, 37(2), 209-231.

García-Chas, R., Neira-Fontela, E., Castro-Casal, C. (2014). High-performance work system and intention to leave: A mediation model. The International Journal of Human Resource Management, 25(3), 367-389. 
Garg, N. (2015). Organizational role stress in dual-career couples: Mediating the relationship between HPWPS, employee engagement and job satisfaction. The IUP Journal of Management Research, 14(3), 43-69.

Gibbs, T., Ashill, N. J. (2013). The effects of high performance work practices on job outcomes. Evidence from frontline employees in Russia. International Journal of Bank Marketing, 31(4), 305-326.

Guthrie, J. P. (2001). High-involvement work practices, turnover, and productivity: Evidence from New Zealand. Academy of Management Journal, 44(1), 180-190.

Hackman, J., Oldham, G. R. (1976). Motivation through the design of work: Test of a theory. Organizational Behavior and Human Performance, 16, 250-279.

Huselid, M. A. (1995). The impact of human resource management practices on turnover, productivity, and corporate financial performance. Academy of Management Journal, 38(3), 635-672.

Huselid, M. A., Becker, B. E. (1996). Methodological issues in cross-sectional and panel estimates of the HR-firm performance link. Industrial Relations, 35(3), 400-422.

Janz, B. D., Colquitt, J. A., \& Noe, R. A. (1997). Knowledge worker team effectiveness: The role of autonomy, interdependence, team development, and contextual support variables. Personnel Psychology, 50(4), 877-904.

Larsen, J. N. (2001). Knowledge, human resources and social practice: The knowledge-intensive business service firm as a distributed knowledge system. The Service Industries Journal, 21(1), 81-102.

Macky, K., Boxall, P. (2007). The relationship between "high-performance work practices" and employee attitudes: An investigation of additive and interaction effects. The International Journal of Human Resource Management, 18(4), 537-567.

Massingham, P., Diment, K. (2009). Organizational commitment, knowledge management interventions, and learning organization capacity. The Learning Organization, 16(2), 122-142.

Messersmith, J. G., Guthrie, J. P. (2010). High performance work systems in emergent organizations: implications for firm performance. Human Resource Management, 49(2), 241-264.
Miles, I. (2005). Knowledge intensive business services: Prospects and policies. Foresight, 7(6), 39-63.

Paauwe, J., Richardson, R. (1997). Introduction to Special Issues on HRM and performance. The International Journal of Human Resource Management, $8(3), 257-262$.

Pocztowski, A. (2008). Zarządzanie zasobami ludzkimi. Strategie, procesy, metody [Human Resources Management. Strategies, Processes, and Methods]. Warszawa: PWE.

Pocztowski A. (2011). Efektywność architektury funkcji HR w procesie tworzenia wartości dla interesariuszy [Effectiveness of HR Architecture in the Process of Creating Value for Stakeholders]. In P. Bohdziewicz (Ed.), Efektywność gospodarowania kapitałem ludzkim [Effectiveness of Human Capital Management] (pp. 39-55). Łódź: Wyd. Uniwersytetu Łódzkiego.

Posthuma, R.A., Campion, M.C., Masimova, M., Campion, M.A. (2013). A high performance work practices taxonomy: Integrating the literature and directing future research. Journal of Management, 39(5), 1184-1220.

Purcell, J., Kinnie, N., Hutchinson S., Rayton B., \& Swart, J. (2003). Understanding the people and performance link: Unlocking the black box. London, UK: Chartered Institute of Personnel and Development.

Robertson, M., Swan, J. (2003). “Control - what control?" Culture and ambiguity within a knowledge intensive firm. Journal of Management Studies, 40(4), 831-858.

Subramony, M. (2009). A meta-analytic investigation of the relationship between HRM bundles and firm performance. Human Resource Management, 48(5), 745-768.

Tregaskis, O., Daniels, K., Glover, L., Butler, P., \& Meyer, M. (2013). High performance work practices and firm performance: A longitudinal case study. British Journal of Management, 24(5), 225-244.

Tsai, C. J. (2006). High performance work systems and organizational performance: An empirical study of Taiwan's semiconductor design firms. The International Journal of Human Resource Management, 17(9), 1512-1530.

Viswesvaran, C., Ones, D. S. (2000). Perspectives on models of job performance. International Journal of Selection and Assessment, 8(4), 216-226. 
Wojtczuk-Turek, A. (2016). Wspieranie produktywności pracowników wiedzy. Rola zarządzania zasobami ludzkimi i dopasowania człowiek-organizacja [Encouraging Knowledge Workers' Productivity. The Role of Human Resources Management and Person-Organization Fit]. Warszawa: Wyd. Naukowe PWN.

Yanadori, Y., van Jaarsveld, D. D. (2014). The relationships of informal high performance work practices to job satisfaction and workplace profitability. Industrial Relations, 53(3), 501-534.

Zhang, B., Morris, J. L. (2014). High-performance work systems and organizational performance: Testing the mediation role of employee outcomes using evidence from PR China. International Journal of Human Resource Management, 25(1), 68-90.

Zhang, M., Fan, D.D., Zhu, Ch. J. (2014). High-performance work systems, corporate social performance and employee outcomes: Exploring the missing links. Journal of Business Ethics, 120(3), 423-435.

Zhu, Ch., Chen, X. (2014). High performance work systems and employee creativity: The mediating effect of knowledge sharing. Frontiers of Business Research in China, 8(3), 367-387.

\section{Acknowledgments}

The research project has been financed with the funds of the National Centre for Science granted under the Decision No. DEC-2013/11/B/HS4/02127 